\title{
QUALITY RELATED PROBLEMS IN LARGE ETHIOPIAN MANUFACTURING FIRMS: IMPLICATIONS FOR COMPETENCY
}

\author{
T. Belai \\ Department of Industrial Engineering \\ Bahir Dar University, Ethiopia \\ ttesemma@yahoo.com
}

\begin{abstract}
This study was conducted in sixteen manufacturing industries in Ethiopia. A structured questionnaire with 52 items (open questions, interviews, and facility observation) was used to collect data. The finding indicates that 55 (about 37\%) of the large manufacturing firms are making significant losses. The main challenges to the industries are poor quality management, poor raw material quality, rising raw material prices, outdated technology, quality costs, inefficient systems, limitations of skills training, and low motivation. Excluding the systems, these factors correlated at about $79 \%$ with market competency. The study also found the widespread use of inspection as a means of problem detection in the manufacturing industries.
\end{abstract}

\section{OPSOMMING}

Sestien groot vervaardigers in Ethiopië is ondersoek. 'n Gestruktureerde vraelys (52 vrae, onderhoude en waarneming) is gebruik vir die versameling van data. Die dataontleding het getoon dat 55 vervaardigers (ongeveer 37\%) in 'n verliessituasie was. Die hoofoorsake was swak bestuursgehalte, swak grondstowwe, stygende materiaalpryse, verouderde tegnologie, gehaltekoste, ondoeltreffende sisteme, opleidingstekorte, en ' $\mathrm{n}$ gebrek aan motivering. Met die uitsondering van sisteemdoeltreffendheid, is daar ' $n$ 79\% korrelasie tussen die hoofoorsake en markbevoegdheid. Die studie het ook gevind dat inspeksie algemeen as probleemopsporingstegniek gebruik word. 


\section{INTRODUCTION}

The policy of the Federal Democratic Republic of Ethiopia for the post-command economy period has placed more emphasis on the agricultural sector. It is often referred to as an agriculture-led development strategy. Ethiopia's industrial development strategic policy (FDRE [7]) is designed primarily to use domestic agricultural products (raw materials) for local industrial production. It appears planned ultimately to link agriculture and industry: agriculture produces industrial inputs, and industry produces agricultural inputs. For example, farms produce wheat for food processing companies, while chemical industries produce fertilizer. The policy-makers thought this would facilitate industrial development which, in turn, would create an adequate market for domestic products in the country under private ownership. In addition to creating favourable conditions for private investors in various sectors of industries, the strategy document also outlines the provision of direct technical supports and necessary services for the following labour-intensive industries, at least as a conceptual framework:

1. Textile and garment industry

2. Agro-processing industry

3. Beef and leather industry

4. Construction industry

In certain zonal administrations, some districts are designated as industrial villages. Infrastructure - such as roads, electric power, and telephone services - is prioritized and directed to these locations. Investors are encouraged to invest in such areas. This might be achieved at the expense of other regions. For example, the policy might serve as an excuse for service agencies (like Ethiopian Electric Power Co) to ignore some areas. At the time of the study, the water bottling industry at Injibara limited its production to the weekends and holidays, owing to serious power shortages, ultimately causing profound impact on investment in the region (Abinet, Adimasu and Habite [1]). The limitations of infrastructure in some areas are characterized as "a serious drawback to industrialization in remote areas" (UNCD[6]).

The significance of available governmental support for industries should be weighed against actual contributions to their compatibilities in a global environment today and in the future, since we live in a pervasive global economic system. The borderless economic system is becoming a reality. For instance, the European Union has embraced within its system not only its member countries: it is also bringing Central and Eastern Europe into its economic influence. The United States of America has set up a Free Trade Zone with Canada and Mexico. Asian and African continents are also moving in that direction. The African Union and Common Market for Eastern and Southern Africa (COMESA) are potential threats to protectionism. In such a free market environment, consumers have more choices about specific products, and so can select the product that meets their requirements. The best weapons for organizational survival and successful competition in the $21^{\text {st }}$ century are product or service quality. Quality is an industry's only insurance that it can compete successfully, whether in regional or world markets. 
Keeping this in mind, it is necessary to assess the experience and conditions of postcommand industry in Ethiopia - particularly large-scale manufacturing firms - and to see whether they fit into the global environment, surviving and competing in the market successfully. No relevant study of quality in Ethiopian manufacturing industries has been conducted so far, and no information is available apart from limited assessments of the textile industry. These studies were based on plant tours in the textile industry, and identified several quality problems. For example, Jeevananthan [12] points to the low quality of raw materials (cotton) and the incompatibility of testing equipment. In his words:

The quality of the cottons available is suitable for spinning counts up to about 40s only, for still finer counts, up to 60s, combing is necessary; there is a strong suspicion that varieties of cottons are mixed and the spinners are not able to obtain varieties suitable for finer varieties because of this reason; stickiness has been a major problem with many varieties of cotton; and strength is also considered low (stelometer bundle strength at $3 \mathrm{~mm}$ gauge ranges from 16-18g/tex).

Jeevananthan found that laboratory equipment was not working in some companies, causing adverse quality process operations. Saminathan and Kathirvelu [18] found that most of the firms used old machinery without reference manuals and original spare parts, as the manufacturers no longer exist. Even with modern machines, a shortage of spare parts is a common problem, owing to foreign currency exchange restrictions or transportation problems. They also found low quality raw material 20s cotton count and below. This results in variations of yarn quality, including variations in yarn length, as observed in the spinning process. Sileshi and Jothi [19] indicated problems in the selection of suppliers for dye and chemical purchases. Sileshi and Jothi also noted quality problems with raw materials for fabric and the dyeing process. Esyas [5] stated that most textile and garment industries struggle with 20-year-old machinery that is unable to meet quality requirements in the market, including incompatibility with dyeing applications.

As regards non-textile manufacturing, Abinet, Admasu and Habtie [1] reported on rework and scrap in plastic bottle production for commercial water bottling, and linked the results to serious power shortages, power supply variations, fluctuating compressor pressure, variations of speed in pre-heater machines, and operator negligence. An officer of the public education department of the Quality and Standard Authority of Ethiopia (QSAE) stated that, among 260 product samples displayed at an exhibition in Addis Ababa, only fifteen were domestic products. Local firms were unable to participate, primarily because of quality problems with their products. He added that domestic products that failed to compete in the local market certainly would not succeed in the international market; consequently, Ethiopia's existence as a nation was in jeopardy. Failure in quality means a failure to survive as a nation, according to this critic. (He made this remark while addressing visiting engineering students at his headquarters on May 30, 2004.)

The objective of the current study is to determine core common quality-related problems in Ethiopian manufacturing industries, and ultimately to evaluate the 
contributions of these factors to the firms' competency in the market. In today's free market environment, there may be no better way of predicting the survival and success of an enterprise than the assessment of its competency in the market. In this context, 'competency' means the actual or probable ability of a manufacturer to gain a market share in a competitive manner, and to sell at least $75 \%$ of its product with a marginal profit in a progressive manner from year to year. By contrast, loss, a low sales record and low demand for the product are indicators of organizational incompetence in the market, leading eventually to collapse. In this study, the manufacturers have scored their competency on a 5-point scale, indicating their overall performance after examining their records.

\section{METHODOLOGY}

\subsection{Target industries and participants}

The sample is comprised of sixteen large-scale manufacturing industries. Among them are eight non-textile public and private enterprises (six located in Addis Ababa, Akaki and Kaliti; one in Bahir Dar, and one at Injibara, Awi Zone. The sample also includes eight textile industries (including private firms), located throughout the country from Adwa to Awassa. Since there are about 150 large-scale manufacturing industries in Ethiopia, the size of the sample $-10.7 \%$ of the total - is acceptable on the basis of experience. The manufacturers' personnel who participated in the study are quality managers/associates/lab technicians, production managers, and salespersons. Government officials in charge of particular public industrial sectors also took part in the interviews.

\subsection{Measurement instruments}

A questionnaire was prepared with 14 categories and 52-pertinent items, consisting of descriptions of quality practices and procedures as practised by quality professionals. Each item/procedure was rated on a scale of 1 to 5: 5 represented a serious problem, and 1 no problem. The questionnaire includes YES and NO questions for each item to ensure that each procedure or activity was practised in the respective firm. If the answer was "NO", the rating was not needed for that particular item. The categories of the questionnaire are listed in Table 1. (The complete items are available from the author on request.) Apart from the YES and NO questions, there were open questions and blank spaces, where the participants were asked to list up to ten common problems in descending order, from serious to mild. On the following page there were additional questions dealing with measures taken, or proposed counter-measures, to cope with the problems. Unstructured questions were also prepared upon arrival at a particular firm's premises, depending on the nature of its production. There were open and unstructured items for the government officials as well. 


\begin{tabular}{|l|l|}
\hline & Categories \\
\hline 1 & Pre-Production Activities \\
\hline 2 & Vendor Relations \\
\hline 3 & Manufacture \\
\hline 4 & Inspection/testing \\
\hline 5 & Customer Relations \\
\hline 6 & Quality Audit \\
\hline 7 & Co-ordination of Quality Work \\
\hline 8 & Organization/Committee \\
\hline 9 & Personnel \\
\hline 10 & Data Feedback, including quality costs \\
\hline 11 & Quality Improvements \\
\hline 12 & Distribution \\
\hline 13 & Timetable (delivery time) \\
\hline 14 & Miscellaneous \\
\hline
\end{tabular}

Table 1: Questionnaire categories

\subsection{Procedure}

In the case of the non-textile firms, the investigator toured each industrial site to conduct the study. Upon arrival, the appropriate administrative unit was contacted and a letter seeking the firm's cooperation was presented in order to obtain permission. The purpose of the study was explained. Permission was usually secured within 30 minutes, except for one firm which scheduled it for the next day. Following authorization, communication was established with quality personnel, the purchaser/salesman, or the production supervisor and purchaser/salesman when quality control was part of a production department. They were also briefed on the objectives of the study and the procedures. The meeting with the investigator was scheduled for a convenient time on the same day, usually within an hour or two.

Data collection took place in the presence of the personnel, in the following manner. Each item in the questionnaire was read by the participant. The investigator (who had a copy in his hand) invited discussion, including explanation of particular items when asked. Discussions were also held among the participants whenever necessary. The relevant data on quality was referred to. Then, the answer YES or NO was determined for the existence of a particular activity in that firm. For example, for the question, "Does the firm practice quality planning?", the answer was either YES or NO. If the answer was YES, the degree of the problem in planning was rated from 'none' to 'serious' on a 5-point scale. If the answer was NO, the next item was dealt with. In the open questions section, the personnel first listed those problems they characterized as serious and more common in descending order, from 'serious' to 'mild'. Then they explained their characterization to the investigator. Next, the problems were listed in the given blank space in the questionnaire. The measures taken or proposed to tackle the problems were also listed, if any. Finally, overall competency in relation to market share was declared numerically on the same scale 
(1 to 5). These evaluations and deliberations were made in a quality control laboratory, production office, or conference hall. All non-textile quality laboratories under study were examined by the investigator, with the exception of one, a military lab. Other related facilities were also visited briefly.

In the case of the textile firms, two were investigated in the same way as the nontextile industries. For the remaining six firms, the respective quality managers, specialists, or production mangers filled in the questionnaire independently, including the open questions. This took place at a symposium on textile and garment sectors, held at Bahir Dar University at the end of April 2004.

\subsection{Results and discussions}

The results of the investigation are narrowed down here to the outstanding factors that have been identified and that are linked to losses and incompetence. The problems related to poor quality management, poor raw material quality, rising raw material prices, outdated technology, quality control costs, limited skills training in quality control, motivation, and system inefficiency. The discussion covered qualityrelated inspection (which is common practice in the industries), including its advantages and disadvantages. The interview results obtained from the public agency are presented first, followed by the assessment of results in the industries, as indicated below.

\subsubsection{Interview results}

The interviews with the concerned officials of the Public Enterprise Supervising Authority [11] in the manufacturing sector indicates that the large-scale manufacturing industries are in recession, risking their survival as organizations. The officials described the performance of the manufacturing industries as very poor. The documents available during the study are also consistent with this description. Fiftyfive large-scale state-owned industries have recorded significant losses, and the losses are increasing daily. That number is estimated to be $36.7 \%$ of existing largescale manufacturing industries in Ethiopia. Among them, 27 industries have already lost $75 \%$ or more of their capital at the time the study. The agro-industry sector has deteriorated the most, due to its large capital involvement.

It is vital to close any enterprise that has recorded $75 \%$ capital loss. The government's financial support for the industries is limited to keeping them alive; the government cannot commit to large-scale investment, since it wants to sell them in accordance with its privatization policy. According to the same source, the causes of the losses in general are linked to:

1. Depreciation-related losses.

2. Length of downtime.

3. Poor quality and market competency.

4. Inadequate equipment/technology.

5. Inadequate operator and managerial skills.

6. Low productivity in comparison with other nations, like China. 
7. Inability of managerial bodies to make appropriate decisions.

8. Unnecessary bureaucratic processes, especially between the respective board and management.

9. Increasing raw material prices, in spite of fluctuations.

The magnitude of the losses differs across the sub-sectors. For example, the profit and loss of ten flour companies and five oil factories vary from year to year. The oil industry appears to be in a weaker position than the flour industry, as can be seen in Table 2.

\begin{tabular}{|l|l|l|l|l|}
\hline $\begin{array}{l}\text { Flour Industry } \\
\text { No. of profit- } \\
\text { makers }\end{array}$ & $\begin{array}{l}\text { No. of loss- } \\
\text { makers }\end{array}$ & Year & $\begin{array}{l}\text { No. of profit- } \\
\text { makers }\end{array}$ & $\begin{array}{l}\text { No. of loss- } \\
\text { makers }\end{array}$ \\
\hline 8 & 2 & 2000 & 0 & 5 \\
\hline 7 & 3 & 2001 & 1 & 4 \\
\hline 7 & 3 & 2002 & 4 & 1 \\
\hline 6 & 4 & 2003 & 2 & 3 \\
\hline
\end{tabular}

Note: Losers \& gainers for 2003 are shown, on the basis of the first 6 month report

Table 2: Flour and oil industries (2003)

According to the same source, the inefficiency of food manufacturing industries in particular is linked to:

1. Raw material shortages.

2. Lack of market competency.

3. High labour costs.

4. Use of inadequate technology compared with foreign competitors.

5. Black market infiltration.

6. Availability of donated foodstuffs at low prices in the domestic market (for example, one litre of oil is available at 8 Birr).

It is important to note that the data illustrated above are limited to the performance of large manufacturing industries at the time of the investigation. Upcoming conditions may be different from the same. For instance, while this paper was in press, Ato Meles Zenawi, Ethiopian Prime Minister in his six months report to a parliamentary session on March 29, 2007, disclosed expected $12.5 \%$ growth in manufacturing industry in general, for the fiscal year 2007. The forecasted growth rate can be assessed and determined in the future.

\subsubsection{Investigation results in industries}

\subsubsection{Low-quality raw materials and high raw material costs}

During the investigation, the personnel of the firms complained about the low quality of raw materials and rising prices. In the open section of the questionnaire, both poor quality raw materials and the prices were emphasized. For all textile industries under 
study, the quality of cotton is more critical than the price. The quality of yarn and fabric is also linked to the quality of the cotton. In addition to the content of the cotton, the suppliers handling or packing varieties of cottons in a single bag (called jonie) contribute to the degradation of the quality of the raw materials. According to the personnel, unmixed cotton definitely results in better quality than mixed. Whether it is low count or high count cotton, machines can be adjusted and the cotton can be processed by spinners for the desirable outcomes; but when the cotton is mixed, it does not fit in any of the processing models. Mixed cotton is difficult to separate for the spinner, and the transfer of defects to the fabric is most likely. As discussed in the introduction, Jeevananthan [12] has also indicated that "varieties of cottons are mixed and the spinners are not able to obtain varieties suitable for finer varieties".

In the non-textile sector, greater importance is given to the quality of raw materials. There also is considerable concern about the price, except it varies across the manufacturing sectors. But, for domestic raw material consumers, low quality raw material is a greater concern than the price. The raw materials produced in segmented individual farming areas are excessively diverse, inconsistent, and showing a considerable degree of nonconformity. For instance, one of the flour factories characterizes domestic wheat as low in nutritional substance and too heterogeneous. Poor rainfall, backward individual farming methods, the absence of national standards on foodstuffs, and mixing varieties of wheat in the same bag (jonnie) are accounted for the problems. The failure of domestic wheat to meet the required quality parameters, as well as inadequate quantities, is a justification for the food processing firms to import wheat for macaroni and spaghetti. To cope with the situations, in the recent years, the government has been encouraging farmers in the north eastern parts of the country in addition to the south eastern farming areas to produce barely and wheat that can meet the requirements of brewery and food processing industries. A result should be assessed in the near future.

For those non-textile firms that depend on imported raw materials, the prime concern is with fluctuating and increasing prices (including transport costs and port taxes). At the time of the study, there is strong dissatisfaction about increasing steel prices, which have an adverse impact on construction firms and individual house builders. The prices of iron appear to be rising constantly. In Bahir Dar and Gondar cities, a 5 $\mathrm{kg}$ package of nails, which was once available for 20-25 birr, now is priced at 45-50 birr; and 12mm reinforcement bars are sold at 70-78 birr per piece, compared with the former price of 20-30 birr. The steel prices, coupled with cement price fluctuations appear to be creating uncertainty in the construction sector in particular. However, since the above figures were obtained from the two cities, these exchange values may not represent the national price index, and are also subject to fluctuation at any time.

It is evident that the manufacturing industries are confronted by unpredictable raw material costs and low quality. The government despite its policy and effort particularly to link agro processing industries with domestic raw materials, its book, Industrial Development Strategic, cited above has neither a specific significant mechanism to improve domestic raw material quality, nor it has clear domestic iron 
ore exploration strategy to support the industries and to minimize the hard currency allocated to steel imports. Although the exact quantity is not known, the existence of the iron ore was recorded at http://eia.doe.gov/cabs/hornafrica.html [10], at the time of this study.

\subsubsection{Poor Management}

Management deficiency is evident in the lack of practical commitment to quality, the absence of written quality policies and objectives, written operational manuals, adequate quality plans, and organization-wide quality systems in the firms. These and other poor quality management indicators are numerically illustrated in Figure 1. Besides that, the lack of problem-solving initiatives and an inability to act proactively as situations demand are common shortcomings in management. As discussed above, based on interviews with the Public Enterprise Supervising Authority officials, the shortcomings of management are significant, and are revealed particularly in the inability to make decisions - a function of management. For example, one of the notable problems in the industries is that communication goes back and forth between the board and the management body even over minor issues that top management could determine by itself. Ashcroft and Rayner [2], who assessed the Ethiopian Higher Education institutions (HEI), also pointed out the tendency to depend on a higher body rather than exercising power and autonomy. In their words:

HEIs leaders are... too dependent on permission from above and even when provided with tools of autonomy are reluctant to lose their dependency on the government to solve their problems.

The correlation of management deficiency with the overall competency of nontextile industries in the market is illustrated in Figure 2.

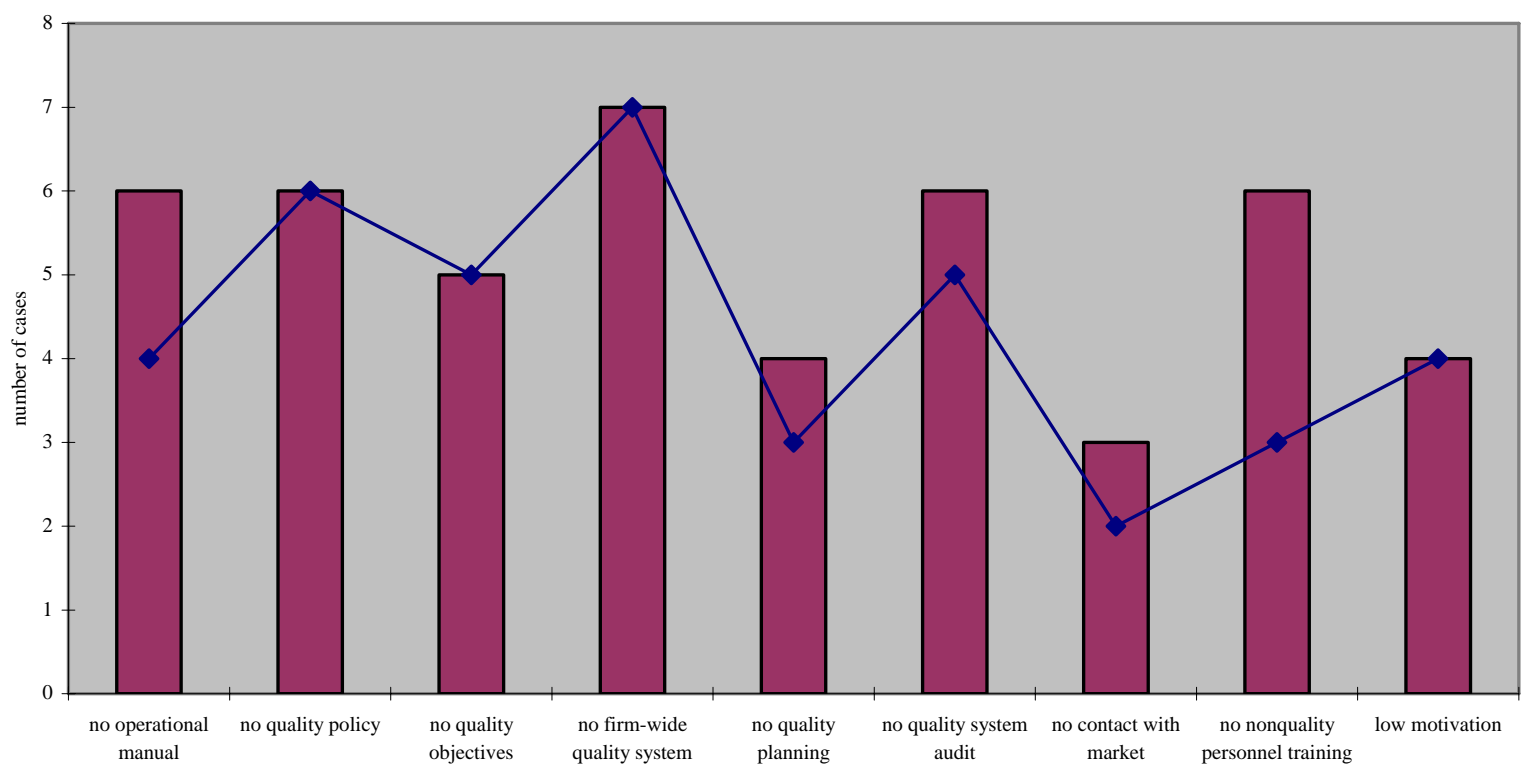

Figure 1: Poor management indicators 


\subsubsection{Impact of technology}

As observed from the eight non-textile industries and the two textile firms, there are challenges associated with outdated technology. For the eight non-textiles, equipment in quality control laboratories is partially functional, mainly due to the unavailability of parts or a shortage of funds to buy equipment. However, seven out of eight declared that their existing lab facilities were more or less adequate to conduct the required basic testing procedures. In the ageing textile factories, the adverse impact of obsolete technology is notable in the finishing departments, in dyeing, and especially in the irregularity of fastening; however, in colour combination an operator's skill and experience is essential. The fading of cloth after it has been washed is particularly linked to a low quality printing process, which is affected by factors such as chemicals, binding devices, and temperature irregularity. In both sectors, some manufacturing machines have neither operational nor maintenance manuals. Spare parts are no longer available for some of the old machines. There is an effort by the spare part metal industry in Ethiopia to produce economical spare parts, to fill the gap. However, the failure to produce a required spare part the first time round is estimated to be at $15 \%$ if the spare part has never been produced by that company before. The failure is linked to poor communication between the customers and the personnel taking orders; misinterpretation of drawings by operators who are not familiar with the function of a particular spare part; or technological limitations in the spare part manufacturing industry itself.

\subsubsection{Quality costs}

Quality costs in this context relate to external and internal failure costs, such as replacement, refund, and rework costs. But this definition does not take into account price increases; indirect losses such as customer desertion due to dissatisfaction with product or delivery; service discrepancies; and costs incurred in the attempt to restore a soiled reputation. The firms were given opportunities to disclose or rate quality costs in their organizations consistent with these descriptions. About 50\% of the nontextile firms rated quality costs at a 'no problem' - level between 1 and 2. Only 25\% acknowledged the problem and rated them 'a serious problem' - level 4. In terms of dollars and cents, the average costs were estimated to be below $1.6 \%$ of total revenue. In the case of textile factories, $37.5 \%$ rated quality costs 'no problem' (levels 1 and 2), but 25\% rated costs in the 'serious problem' category (levels 4 and 5). The costs were estimated to be within the range of $2 \%$ to $2.1 \%$ of total revenue. Given the magnitude and many dimensions of the quality problems discussed in this paper, the firms' own ratings of quality costs are very low. The actual quality costs are not as low as claimed by the companies; the costs are very likely to be much higher than the figures described here. There are reasons for quality costs being reported as low. First, Ethiopian customers and manufacturers are unaware of the situation in developed nations. Second, in rural Ethiopia many choices are not available to consumers. As a result, customers accept the product offered to them, no matter the quality, with few objections. Therefore, the quality costs are apparently low - from the manufacturer's point of view. Third, most of these companies' products are not sold in the international market, and so the manufacturers do not face international quality standards and are not aware of the actual quality costs. 
Fourth, the low ratings and estimates indicate the absence of comprehensive quality cost systems, which are a powerful means of decreasing or eliminating financial loss in hard-pressed organizations. The author did not find comprehensive cost-tracking mechanisms in the industries visited. In other words, in the absence of relevant quality cost systems, reliable quality cost data should not be expected. As mentioned above, it seems these are valid reasons for the industries to lower their estimate of quality related costs. Literature on quality shows that principles and factors involved in quality cost determination can vary from organization to organization. However, the costs of external and internal failure, as well as appraisal and prevention costs, are commonly tracked. These factors are analyzed, summarized, and presented in figures (such as a Pareto diagram) to compare and contrast for further actions presumably in organizations with acceptable quality cost systems. To achieve organizational effectiveness and efficiency, both means of tracking quality-related costs and corrective actions are important. It is common knowledge that in many organizations, shifting the trend from failure costs to prevention costs is considered a positive step.

\subsubsection{No organization-wide quality system}

The industries under study have no organization-wide quality systems that enable the employees to make active contributions to problem-solving, prevention, and quality improvement. Seven of the eight non-textile industries have no comprehensive quality program. But in one flour factory there is progress towards the introduction of total quality management in the company: it has begun to use an X-chart for process control. It has provided training in quality for 50 employees who are not quality department personnel. It has also involved the executive manager in quality affairs. It has established relations with wheat suppliers to improve quality. The National Agriculture Research Centre has been approached to consider seed quality before it approves seed in an extension program. These are important elements in the TQM approach as widely addressed in literature, including Oakland [17]). There are also two textile industries that claim to have a comprehensive program, but these could not be verified by the investigator owing to his inability to travel to their premises. For both sectors, strong indicators of the absence of an organization-wide quality program are the misconceptions of employees about quality department personnel, and the prevalence of the outdated philosophy, "Leave quality to the quality department”. Quality department associates in both sectors reported that they were perceived as "traditional police" by their fellow co-workers. Consequently, quality department personnel are systematically isolated from informal social interactions in these organizations. The responses of the employees to quality control appear simply to avoid perceived adverse consequences brought on them by the quality controllers, rather than to seek the welfare and success of the organization. In such a climate, progress in quality may be unattainable.

\subsubsection{Training beneficiaries}

The beneficiaries of quality training are the quality department personnel, as assessed in the non-textile sector. Usually, neither the top executives who have decisionmaking power, nor the ordinary employees, take part in quality training, except on 
rare occasions. In Addis Ababa and its environs, most of the training is provided by the Quality and Standards Authority of Ethiopia. The quality department personnel who have received training are unable to bring about desired changes in quality aspects. Because of the top leadership's ignorance on the role of quality for success, it is hard for quality department associates to secure commitment from the top to disseminate the knowledge and skills acquired during training of fellow employees in an economical manner. On the other hand, due to established negative expectations, some of the quality department associates do not take the initiative in mobilizing employees for organization-wide quality activity. Training so far has been unable to create a functional quality system, beyond drawing structures on paper. For example, in the case of two companies there have been quality committees on paper for more than two years, but in reality they have achieved almost nothing, and are likely to be abolished. Prominent Western quality gurus, Deming, Juran and Corsby, have emphasized the commitment of top management as a precondition to the success of a firm's quality programme. The training contribution to overall market competency is shown in Figure 2.

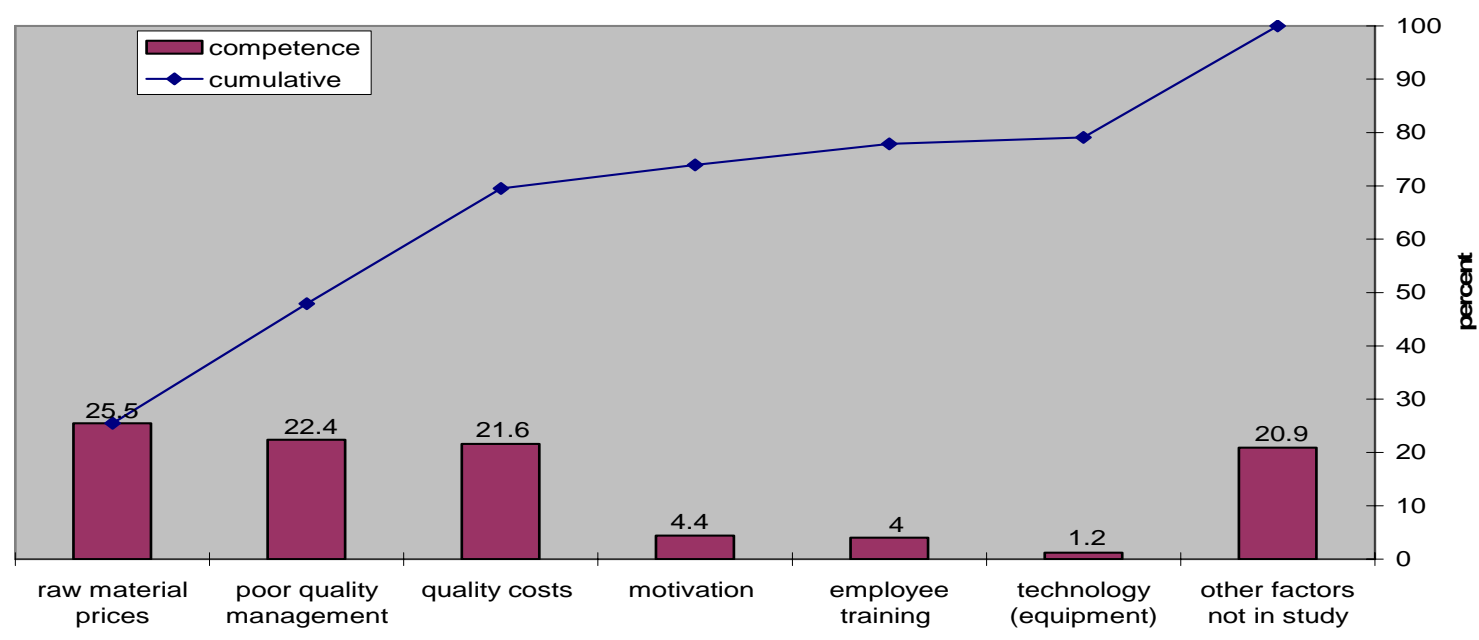

Figure 2: Multiple regression coefficients transferred to percent

\subsubsection{Motivation}

In the present study, $50 \%$ of the non-textile manufacturing firms complained about

low employee motivation; $30 \%$ of the textile firms complained about serious problems, while $20 \%$ of the textile firms said their employees experienced moderate motivation (3 points on the scale). The lack of initiative for problem-solving and the low sense of belonging are common syndromes in the industries. Two firms, including one private textile factory, are also critical of new college graduates. They contend that new graduates not only lack achievement motivation but also suffer from role confusion. There is a misconception that the engineering profession is the route to a comfortable chair in employment, and consequently there is no readiness to wear a uniform and work in a workshop. 
For many writers, motivation is the driving force behind human achievement. The overall output of an organization depends on the performance of its employees as individuals and as a group. Without considering human behavior, there is little understanding of organizational performance. In other words, without understanding motivation, we cannot see how variations in job design, styles of leadership, incentives, and human relations influence performance and productivity. A number of sources of motivation can be summarized as follows (Kinard [14]):

1. Need: the intrinsic force that causes a course of action or human behaviour

2. Expectancy: the cognitive or mental process that leads to decisions to take action

3. Incentive theories: these describe external factors that motivate, such as salary increase, bonus, recognition, and medical benefits.

For Deming, one of the West's quality gurus, poor motivation is a response to 'master style', autocratic management behaviour. However, it should be noted that performance should not depend on motivation alone. In spite of the fact that motivation is a major factor for human achievement, other variables, like culture, perception, ability, experience, and technology should also be considered. In the 1980s, it was proposed that performance $=$ ability $(\mathrm{a})+$ motivation $(\mathrm{m})+$ perception (p) (see Mitchell [15], p. 159). This formula may no longer be the sole expression of the degree of performance, since operator experience (e), technology (t), and culture (c) also have a significant impact, in addition to the three classic performance components. It is therefore fair to say Performanc $e=a+m+p+e+t+c$. The productivity of Ethiopian employees is low, as the mass media frequently say. The productivity ratio of Chinese employees to Ethiopian employees for the same job was said to be 7:1. This report might be exaggerated; and I believe that the cause of low productivity and poor quality cannot be fully explained without taking into account comprehensive factors including the six variables mentioned in this paragraph.

\section{THE CORRELATION BETWEEN MARKET COMPETENCY AND AFFECTING VARIABLES}

As described in the methodology section, six out of eight textile firms participated in the workshop study. Apart from their work stations, their facilities were not visited by the investigator. The variables on competency and technology were not rated as was done in the case of the non-textile firms. Consequently, the multiple correlation analyses below are limited to the data on non-textile firms.

The core factors that affect the competency of Ethiopian manufacturing firms in the market are diverse. They include poor quality management, rising raw material prices, outdated technology, quality costs, limited skill-training in quality, and poor motivation, along with other factors discussed above. The degree of impact differs from one variable to another. To determine the weight of each factor and as a group in combination in relation to competency, it is imperative to run the statistical test, multiple regression analysis, beyond the TQM tradition, which usually uses one-toone correlation in a scatter graph. As a matter of statistical tradition, it is assumed that a dependent variable is random, the independent variables and dependent 
variable are associated with a linear relation, and random variables have equal variance. Although the sample for regression analysis is small, there are good reasons to employ regression analysis. First, it is organization-wide data that has been collected and rated collectively, not an individual employee's point of view. Second, thanks to powerful modern computer software, a possibly large multiple correlation value $(R)$ - what is called $R$ inflation - that may result from a small sample size is controlled automatically via an R-adjustment mechanism. In traditional statistical literature, when the sample size is small, $\mathrm{R}$ inflation is corrected by applying mathematical computation, to give a better measure of the population $\mathrm{R}$ - for instance, the use of the following formula, given by Garrentt [9]:

$\bar{R}^{2}=1-\mathrm{K}^{2} \frac{(n-1)}{(n-m)}$

Where $\mathrm{n}=$ sample size $\mathrm{n}-\mathrm{m}=$ degree of freedom

$\mathrm{m}=$ number of independent variables $\mathrm{K}^{2}=1-\mathrm{R}^{2}$

On the basis of the justifications above, regression analysis is considered and carried out on a computerized model, available at Addis Ababa University's Department of Statistics. The outcomes of the coefficients of correlation (r) are interpreted and summarized below. For simplicity, the technical tables of the test of significance and partial coefficient of correlation are not included in this report. Only the coefficient correlations, which are converted to percentages, are presented in Figure 2. As can be seen, some variables correlated inversely, although their degrees of correlations differ across the variables. For instance, raw material prices, quality costs and competency related inversely; this means that increases in both costs minimize competency in the market. Stronger correlation is revealed between raw material costs and competency (25.5\%), poor management and competency (22.4\%). Conversely, a low correlation is shown between technology and competency (1.2\%). This is because, in present Ethiopian industrial conditions, technological impact is masked by other immediate problems listed herein, creating subtle biases in rating. When technological impact was assessed, making the other five variables constant statistically or mathematically, its correlation was 0.443 , more than ten times larger than the figure in the first case; but when it comes to its proportion in combination, it is masked by the other problems. Correlation of all the variables or multiple $\mathrm{R}^{2}$ is 0.970 (adjusted or corrected by computer, $\mathrm{R}^{2}=0.791$, which means $79.1 \%$ of competency in the industries under study is dependent on these six factors). It should be noted that the coefficient correlations are descriptive statistics, which indicate whether there is a strong association between the independent variables and the dependent variable. The test is statistically insignificant at $1 \%$ or $5 \%$, but it is significant at $\mathrm{F}=5.42$, df $=6 / 1, \mathrm{p}<0.3$, which is a computer outcome. The level of significance is unusually high, due to the small sample size and large number of independent variables (six) in the problem. The large number of independent variables reduces the degree of freedom (df) and eventually undermines the outcome of the test of significance, as links between $\mathrm{df}$ and $\mathrm{F}$ value are inverse. It seems to be a technical matter rather than reality on the ground. According to Garrentt [9], a small R-value with a small sample size and a large number of independent variables should be interpreted with caution. 


\section{INSPECTION: COMMON PRACTICE FOR PROBLEM DETECTION}

Inspection is a well-known quality control technique. In its early stages, it was used to inspect finished goods to detect defects or nonconformities. Later it was referred to as a symptom treatment procedure. Nowadays, inspection is supplemented by other procedures for process control, in the form of sampling to check whether a process is capable of producing or meeting specified product parameters before waste is incurred, or whether a given process is out of control or not is determined through statistical process control charts or other appropriate indicators. When the process deviates from the required tolerance limits, sources of problems - known as 'assignable causes' - are detected and necessary remedial correction is undertaken to restore the process to a desirable condition, and a prevention mechanism to avert the reoccurrence of the problems is devised. To that extent, inspection is a legitimate quality control activity. If the inspection is employed to count a number of defects, to determine the proportions of defects, to remove bad items from good ones, or to mask poor quality just to enter the market, then that is symptom treatment, because knowing the proportion of defects or removing the defects does not itself solve the causes of defects. In that sense, inspection does not have a pertinent role in quality improvement, and it should not be considered as a quality management programme.

The fact is that inspection is widely employed in all the industries the author studied. It is classified into in-process inspection, incoming inspection and finished goods inspection. In-process inspection takes samples in manufacturing or while in process. The result is compared with what is called 'standard' or 'specification'. Upon deviation, a corrective measure is undertaken to control waste; in the worst case, production is stopped until the machine has been repaired. It is conducted by quality personnel, or by an operator. However, quick process indicative tools, like control charts for variables or attributes, are almost unknown in the industries. Out of eight non-textile industries in the study, one food processing industry had just started developing an $\bar{X}$-chart. The chart, with 10 samples, and 8 to 12 observations in each, giving a total of 92 samples, shows the product is within specification limits (Figure 3). On the basis of the company's requirements, the percentage content of moisture in macaroni flour is obviously within specification limits, but this does not necessarily mean the process is under control; that has to be checked via control limits ( $C L=\overline{\bar{X}} \pm A_{2} \bar{R}$ ), because specification limits may be equal to or vary from the control limits. According to an operator there, the upper specification limit of the data is relatively small - that is, the company wants low moisture content so that the product can be kept in storage for longer when demand is low.

Incoming inspection is conducted when the raw materials arrive on the premises, to check whether the items conform to the purchase specification and pre-purchase samples. The percentage of incoming raw materials that is inspected varies from company to company and from article to article. The declared range is estimated to be $0.1 \%$ to $2.5 \%$. The average outgoing quality after rectification is always better than the incoming quality, since defects are removed or replaced with normal items. See Figure 4 for the OC curve constructed on the estimated data from the study, where the number of defects for acceptance and the sample size are 1 and 100 respectively. In exceptional cases, significant variation between the sample sent prior 
to agreement and actual raw materials arriving is detected through incoming inspections. It is reported that untrustworthy suppliers ship poor raw materials inconsistent with the pre-purchase samples. These problems are obviously related to poor vendor evaluation and selection. Even after appropriate selection, in the TQM approach, consumers are strongly recommended to use a single vendor (or a few) rather than having many suppliers. The development of a positive vendor-consumer relationship, which is called quality function development (QFD), fosters mutual concerns through bilateral interests. In turn, this leads to the maintenance of raw material quality with required quantity and quick response. In such conditions, need for the acceptance- sampling plan becomes irrelevant. Besterfield [3], for instance, reported a decline in the stipulation for acceptance sampling plans as suppliers improved their process control in the United States of America.

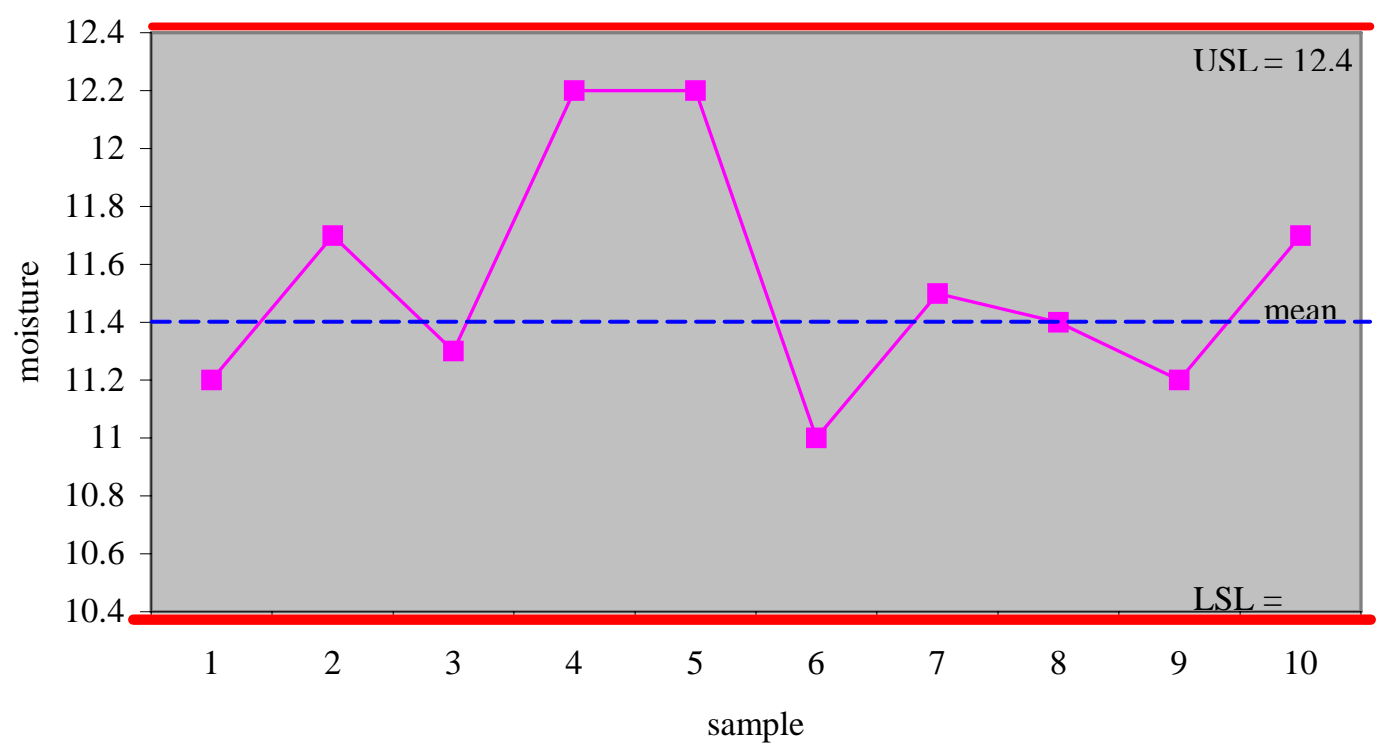

Figure 3: Moisture in macaroni flour

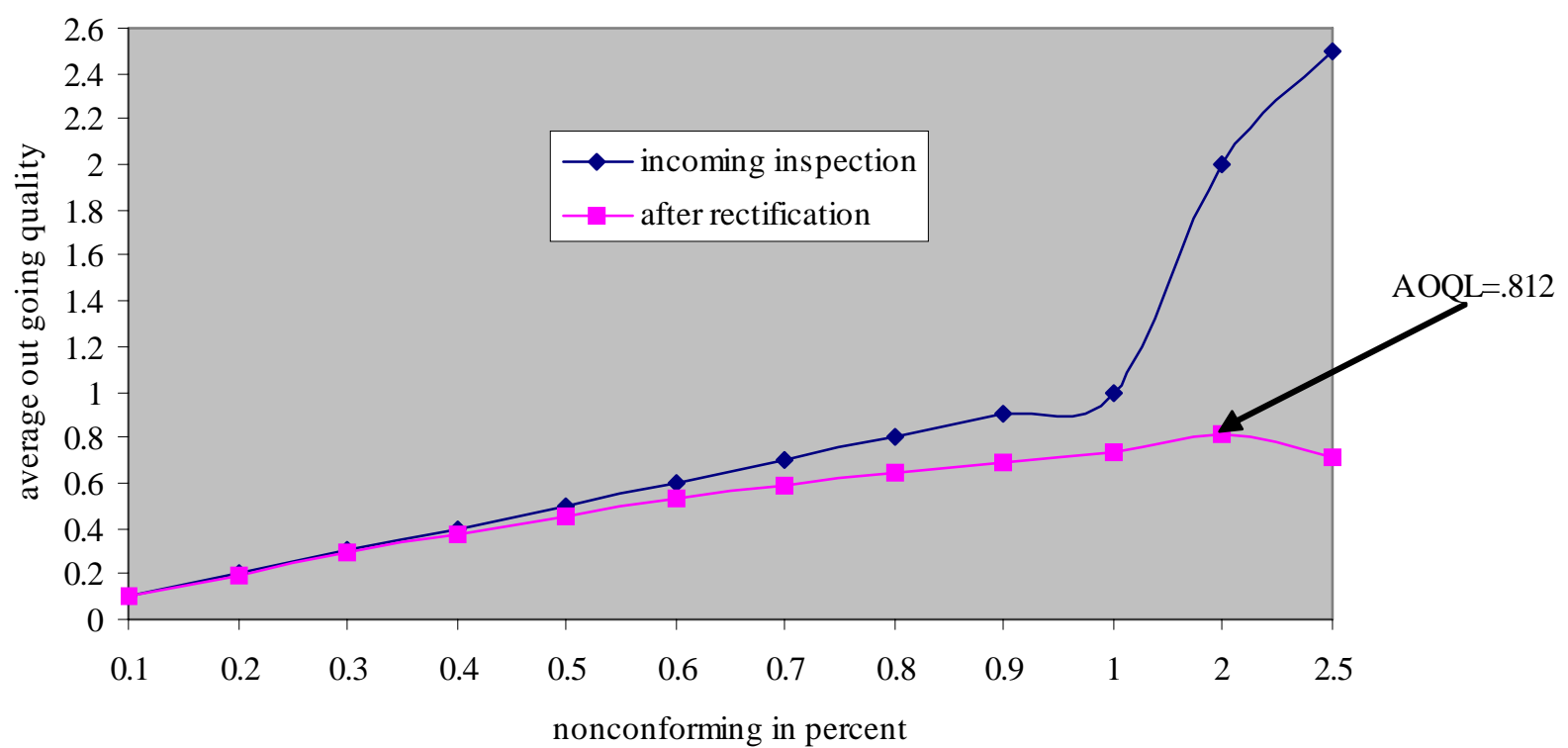

Figure 4: Inspection results 
'Finished product' or 'output' inspection is also common in the industries studied here. Outputs are measured against standards or specifications. Defects are removed or returned for rework. The percentage of non-conformity to specifications or standards differs from product to product, and from one firm to another. It is reportedly estimated to range from $0.5 \%$ to $4.3 \%$ in normal production conditions for non-textile industries. This is high in comparison with advanced industrial nations like USA, Japan, and Germany, which "are working to attain 99.99997\% defect free or even zero defect production" (Jain and Chitale [13], p. 2). In this study, the nonconformity rate for the textile industries is much higher than non-textile industries. In one of the textile factories, the investigator found a nonconformity rate of $4.55 \%$ in finished fabrics in a weekly report, and a nonconformity rate of $93.23 \%$ in yarn

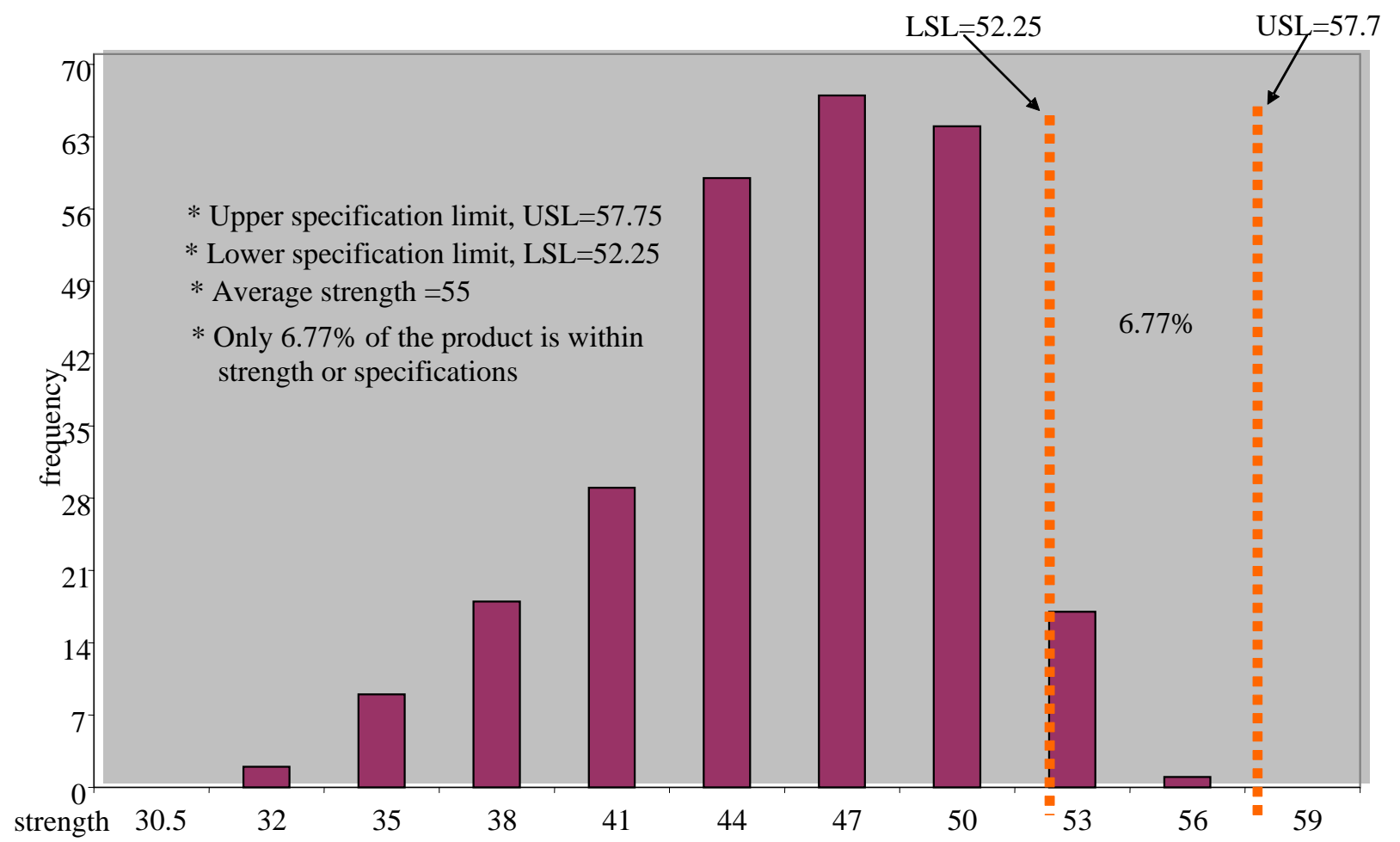

Figure 5: Yarn $20 \mathrm{Ne}$

strength of $20 \mathrm{Ne}$ (English yarn count) according to yearly average data (Figure 5). It is contended by Jeevananthan [12] that:

$90 \%$ of the yarn quality can be attributed to the raw material quality and the processing can at best maintain the yarn quality by better machinery maintenance. This should include adequate house keeping, choice of appropriate process parameters and adequate process/quality control techniques. 


\begin{tabular}{|c|c|c|c|c|c|c|c|c|}
\hline \multirow{3}{*}{ Sr No } & \multirow{3}{*}{ Article } & \multicolumn{6}{|c|}{ GRADES } & \multirow[b]{3}{*}{ Total } \\
\hline & & \multicolumn{2}{|c|}{ High Quality =2 } & \multicolumn{2}{|c|}{ Moderate =1 } & \multicolumn{2}{|c|}{ Defect $=0$} & \\
\hline & & In Mts & $\%$ & In Mts & $\%$ & $\begin{array}{l}\text { In } \\
\text { Mts }\end{array}$ & $\%$ & \\
\hline 1 & Sheet $180 \mathrm{~cm}$ & 4192 & 100 & & & & & 4192 \\
\hline 2 & Abay shema 75 & 1986 & 100 & & & & & 1986 \\
\hline 3 & Regular Sheet 54 & & & 781 & 100 & & & 781 \\
\hline 4 & Abujedi 150 & & & 6979 & 87.34 & 1012 & 12.66 & 7991 \\
\hline 5 & Muhamudie 91 & 5938 & 99,62 & 22 & 0.37 & & & 5960 \\
\hline 6 & Kuta 91 & 2026 & 85.56 & 342 & 14.44 & & & 2368 \\
\hline 7 & Kuta 120 & 2026 & 85.56 & 342 & 14.44 & & & 2368 \\
\hline 8 & Sheet 54 & 6097 & 80.62 & 1466 & 19.38 & & & 7563 \\
\hline 9 & Regular Sheet 160 & & & 3222 & 100 & & & 3222 \\
\hline 10 & Exp. Sheet 165 & 18954 & 77.64 & 5193 & 21.27 & 266 & 1.09 & 24413 \\
\hline 11 & Sheet 54 & & & 6668 & 82.36 & 1428 & 17.64 & 8096 \\
\hline 12 & Abujedi 91 & 14332 & 92.9 & 1096 & 7.1 & & & 15428 \\
\hline 13 & Abujedi 150 & 14332 & 92.9 & 1096 & 7.1 & & & 15428 \\
\hline 14 & Exp. Sheet 190 & 3635 & 96.78 & 121 & 3.22 & & & 3756 \\
\hline 15 & Abay Sheme 150 & 3549 & 90.88 & 356 & 9.12 & & & 3905 \\
\hline 16 & Kuta 91 & 3040 & 79.41 & 788 & 20.59 & & & 3828 \\
\hline 17 & Kuta 150 & 3040 & 79.41 & 788 & 20.59 & & & 3828 \\
\hline Total & & 83147 & 72.23 & 29260 & 25.42 & 2706 & 2.35 & 115113 \\
\hline
\end{tabular}

Table 3: Grey fabric quality classification

The defects in finished open clothes in Table 5 are cumulative from weaving and finishing processes, as illustrated in Table 4. The expected nonconformity for open clothes is $2 \%$. Compared with this figure, the company's $4.55 \%$ actual defect level (Table 5) is significantly high. Table 3 is the grade categories of finished products on the basis of quality. It shows defective, moderate, and high quality respectively columns 0,1 , and 2, from right to left. Its grading technique is arbitrary, and lacks clear objective standards / specifications for the basis of classification. Consequently, it can be subject to the individual judgment of inspectors. The product in Column 2, labeled "high quality", may be categorized under Column 1 ("moderate") by another inspector, depending his/her experience and merits. In one case, for example, white fabric was passed for export by an inspector. Then the product sample, about 4 meters, was sent overseas as part of promotion and market research. A couple of weeks later, the sample was returned, with feedback. The potential consumer generally favored the fabric, but five spots were identified and circled with blue ink for the manufacturer's attention, requiring remedial action to be taken for quality improvement. The spots were insoluble, made of grey fibers transferred from old cotton bags called jonnie. Although the spots were visible to the naked eye, the inspector had failed to see them. If there had been a clear, objective control procedure to separate conformity from nonconformity, the incident could have been avoided. It occurred even though the textile industry had developed a reliable measurement technique; but it was complicated by lack of access to proper instruments and techniques, and by operator skill limitations. 
Weaving Defects (Mts)

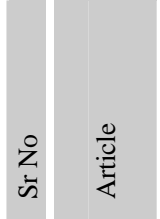

D.

1 Sheet

$137 \mathrm{~cm}$

Export

2 Sheet

$165 \mathrm{~cm}$

Export

3 Sheet

$160 \mathrm{~cm}$

D.

4 Sheet

$180 \mathrm{~cm}$

D.

5 Sheet

$160 \mathrm{~cm}$

Export

6 Sheet

$190 \mathrm{~cm}$

Grand

Total

$\mathrm{D}=$ domestic - none

$229.80 \quad 174.07$
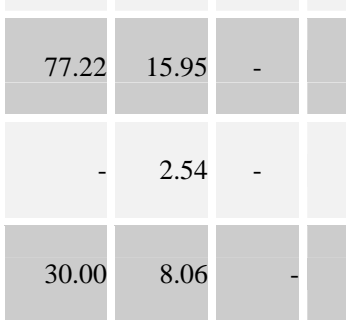

Finishing Defects (Mts)
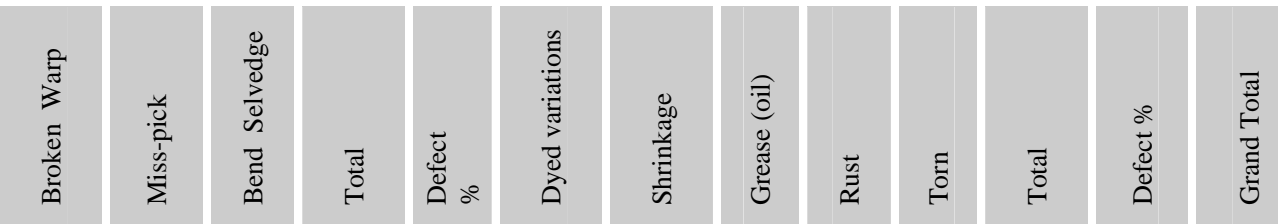

403.87

$6 \quad 160.75$

$119.52 \quad 12.07$

$16.19 \quad 308.53$

1.99

712.40
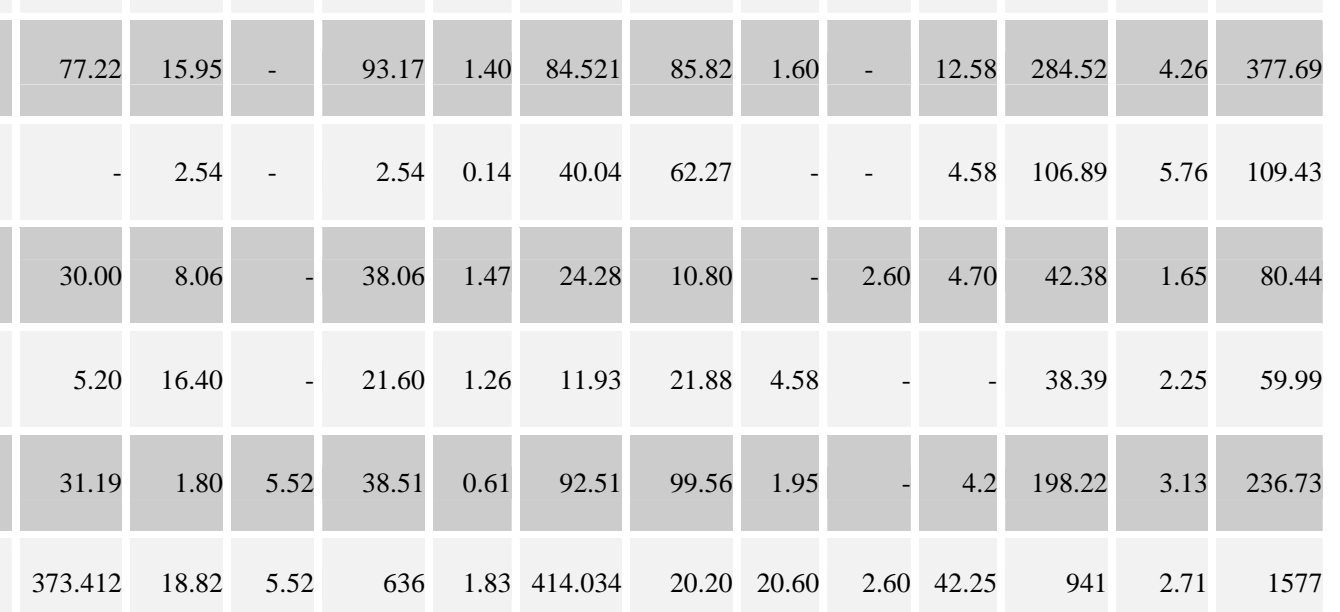

Table 4: Weaving and finishing defects

\begin{tabular}{|c|c|c|c|c|c|c|}
\hline \multicolumn{7}{|c|}{ GRADES } \\
\hline $\begin{array}{l}\text { Sr } \\
\text { No }\end{array}$ & Article & $\begin{array}{c}\text { Quality } \\
\text { (Mts) }\end{array}$ & $\%$ & $\begin{array}{c}\text { Defects } \\
\text { (Mts) }\end{array}$ & $\%$ & $\begin{array}{c}\text { Grand } \\
\text { Total }\end{array}$ \\
\hline 1 & $\begin{array}{l}\text { D. } \\
\text { Sheet } \\
137 \mathrm{~cm}\end{array}$ & 14788.8 & 95.40 & 712.4 & 4.6 & 15501.2 \\
\hline 2 & $\begin{array}{l}\text { Export } \\
\text { Sheet } \\
165 \mathrm{~cm}\end{array}$ & 6307.6 & 94.34 & 377.69 & 5.66 & 6685.29 \\
\hline 3 & $\begin{array}{l}\text { Export } \\
\text { Sheet } \\
165 \mathrm{~cm}\end{array}$ & 1747.2 & 94.10 & 109.43 & 5.9 & 1856.63 \\
\hline 4 & $\begin{array}{l}\text { D. } \\
\text { Sheet } \\
180 \mathrm{~cm}\end{array}$ & 2496 & 96.88 & 80.44 & 3.12 & 2576.44 \\
\hline 5 & $\begin{array}{l}\text { D. } \\
\text { Sheet } \\
160 \mathrm{~cm}\end{array}$ & 1648.4 & 96.49 & 59.99 & 3.51 & 1708.39 \\
\hline 6 & $\begin{array}{l}\text { Export } \\
\text { Sheet } \\
190 \mathrm{~cm}\end{array}$ & 6104.8 & 96.26 & 236.73 & 3.74 & 6341.53 \\
\hline Grand Total & & 33092.8 & 95.45 & 1577 & 4.55 & 34669.48 \\
\hline
\end{tabular}

Table 5: Proportion of conforming and nonconforming products as computed by the firm, B. Dar T. Share Co.

In developed countries - for example, in the USA - SPC tools like "c \& u” control charts are used in such quality situations. The c-chart controls the count of 
nonconformity, while the u-chart is appropriate for counting nonconformity per unit. Since both attribute charts are specified by upper and lower control (tolerance) limits, they are a simple tool for an inspector or operator to compare the number of defects or proportion of defects per unit or in unit. Further examples are found in Besterfield [3], Grant and Leavenworth [8], and Montgomery [16]. When a process central line (mean) is available, computation of the central value is not required. The same value should serve as a reference for the process.

\section{CONCLUSIONS}

The findings of this study are important. However, further study is recommended for a more considered inference. Proposing specific countermeasures to the problems is beyond the scope of this study. However, in general terms a comprehensive framework or a functional national policy is needed for the improvement of the quality of domestic raw materials, enabling the replacement of costly imported materials by domestic inputs. In the long run, iron ore exploration and the development of string plants in Ethiopia could be part of a strategy to offset spiraling raw material prices, as well as related transport and port costs. Taguchi, a prominent Japanese quality guru in the 1980s, recognized the use of economical raw materials in process, design, and product development, but without compromising quality. Of course, the quality of products manufactured from low cost materials is tested via prototype (pilot product) before mass production for the market. According to Taguchi, "Nothing is more foolish than research using high priced materials and components" (Besterfield et al. [4], p. 394). The justification behind this principle is that, when a product is manufactured at a lower cost with superior quality, this empowers the firm to sell its quality product at reasonable prices, thus disadvantaging competitors who incur higher costs to produce the same product.

In addition to the above strategy, the industrial community should strengthen its cooperation in bulk raw material purchase and other immediate mutual interests in order to meet global and regional competition. Within an organization, countermeasures need to focus on system-wide improvement, as outlined in the TQM approach and philosophy, rather than focusing on a single quality department, which cannot bring about significant changes to organizational culture and attitudes. A comprehensive approach is essential in order to improve the quality of industrial products that can be made available to the market at reasonable prices. This could eventually empower organizations, and increase the likelihood that they survive and increase their competency in competitive markets.

\section{SUMMARY}

This study was conducted to determine quality-related problems in large-scale manufacturing industries in Ethiopia. It was also designed to establish the factors that link to firms' competency in the market. The investigation focused on eight nontextile and eight textile firms. A structured questionnaire with 52 items (open questions, interviews, and facility observation) was used for data collection. The investigation found that 55 (about 36.7\%) large manufacturing industries experience significant losses. The most significant problems facing the industries are poor raw 
material quality, rising raw material prices, poor quality management, outdated technology, quality costs, system inefficiency, limited skills training, and low motivation. Excluding system inefficiency, the firms' declared competency in the market is correlated with these factors, respectively, at $22.4 \%, 25.5 \%, 1.2 \%, 21.6 \%$, $4 \%$, and $4.4 \%$,

In the case of the non-textile manufacturers (as indicated in Figure 1), $75 \%$ have no written quality policy, $87.5 \%$ have no organization-wide quality system, $62.5 \%$ have no written quality objectives, $75 \%$ have no operational manual, $75 \%$ of the quality training is targeted only at quality personnel, and $50 \%$ of the firms admitted a lack of motivation among their employees.

In the case of the textile manufacturers, $75 \%$ have no written quality policy, $87.5 \%$ have no organization-wide quality system, $62.5 \%$ have no written quality objectives, $50 \%$ have no operational manual, $37.5 \%$ of quality training is targeted only at quality personnel, and $50 \%$ of the firms complained about low motivation among their employees. Ageing technology and low cotton quality are prime concerns for these industries.

Despite the fact that the quality problems are pervasive in both sectors of the industries, the quality-related costs are rated low $-1.6 \%$ and $2.1 \%$ of the revenues respectively for non-textile and textile firms. The actual quality costs are considerably higher than these figures suggested. The low ratings and estimates are likely due to the manufacturers' lack of awareness of quality and its costs. The author also note the absence of comprehensive quality cost systems for tracking qualityrelated costs and for developing remedial means to avoid losses. These reasons explain, to some extent, the industries' low estimates of quality costs (1.6\% to $2.1 \%)$. Literature on quality indicates that mechanisms and factors applied in quality costs determination can differ from firm to firm; however, the cost of failures and appraisal and prevention costs are commonly dealt with.

This study has also found a widespread use of inspection as a way of detecting problems in incoming materials, in process, and in finished goods in both sectors. The proportion of defects varies across the firms and the nature of products. The range of nonconformity revealed in incoming inspection is estimated to be $0.1 \%$ to $2.5 \%$; for finished goods, it is estimated to range from 0.5 to $4.3 \%$. The nonconformity rate is presumably greater in the textile sector than in the non-textile sector. During this study, a nonconformity rate of $4.55 \%$ is identified in finished fabric products in one of the firms. In one case, the yarn strength of $20 \mathrm{Ne}-93.23 \%$ of yearly average data - is outside specification limits. The use of process control tools, such as variable/attribute charts, is almost unknown in the industrial community.

The outcomes of this study are important, but further study is recommended before inferences are drawn. Proposing specific solutions to the problems is not part of this study. In general terms, a comprehensive national policy is required to improve the quality of domestic raw materials, to replace costly imported raw materials with economical domestic inputs, and in the long term to search for iron ore to minimize 
costs related to imported materials. This should be implemented without compromising quality. The industries need to foster cooperation among themselves, not least in bulk purchasing. Organizational countermeasures should focus on improving organization-wide systems, rather than just on a single department or unit.

\section{ACKNOWLEDGEMENT}

I acknowledge Mr P.N.R. Jeevananthan (Faculty) and Mr D. Jothi (Faculty) (a former quality manager in India), Textile Engineering Department, BDU, for their valuable comments on the draft manuscript. I also thank others who gave their support directly or indirectly to the completion of this project.

\section{REFERENCES}

[1] Abinet, T. Admasu, Y. and Habtie, Z. 2004. Quality in top land, mineral water bottling industry, Final year project available from Industrial Engineering Department, Faculty of Engineering, Bahir Dar University.

[2] Ashcroft, K. and Rayner, P. 2004. Draft report on progress in Ethiopia's higher education system: Democracy, developing responsible citizens, operational effectiveness, research and consultancy, Unpublished paper presented at Higher Education Teacher Conference.

[3] Besterfield, D.H. 1994. Quality control, $4^{\text {th }}$ ed., Prentice Hall Career \& Technology, Englewood, New Jersey.

[4] Besterfield, D. H. et al. 1999. Total quality management, $2^{\text {nd }}$ ed., Pearson Education Asia, Patparganj, Delhi.

[5] Esyas, A. 2004. The challenges of the Ethiopian textile and garment sector on the opportunities of the African growth opportunity acts (AGOA) and impact of phasing out of multi arrangement (MFA) 2005. Unpublished paper presented at Bahir Dar University Textile \& Garment Symposium.

[6] Ethiopia's NAP in the context of the UNCCD. Ethiopia's industrial sector strategy, retrieved September 8, 2004 from http://www.gm-unccd.org.

[7] FDRE. 2002. Ye-Industry Limat Strategy (Industrial development strategy), Ministry of Information and Press, Addis Ababa.

[8] Grant, E.L. \& Leavenworth, R.S. 1996. Statistical quality control, $7^{\text {th }}$ ed., Tata McGraw-Hill, New Delhi.

[9] Garrentt, H.E. 1962. Statistics in psychology and education, $5^{\text {th }}$ ed., David McKay \& Company, New York.

[10] Horn of Africa 2002. 'Economy', retrieved June 16, 2004 from http://eia.doe.gov/cabs/hornafrica.html

[11] Interview with Mr Daniel Banti and Luol Seged. June 5, 2004, Public Enterprise Supervising Authority.

[12] Jeevananthan, P.N.R. 2004. Ethiopian textile industry study report spinning, Unpublished paper presented at Bahir Dar University Textile \& Garment Symposium.

[13] Jain, C.K. and Chitale, K. A. 2003. Quality assurance and total quality management: ISO- 9000, QS-9000, ISO-14000, Khanna Publisher, Delhi.

[14] Kinard, J. (1988). Management, D. C. Health and Company, Lexington, Massachusetts. 
[15] Mitchell, T.R. 1982. People in organizations: An introduction to organizational behavior, McGraw-Hill, New York.

[16] Montgomery, D.C. 2001. Introduction to statistical quality control, $3^{\text {rd }}$ ed., John Wiley \& Sons, New York.

[17] Oakland, J.S. 1993. Total quality management, $2^{\text {nd }}$ ed., ButterworthHeinemann, Jordan Hill, Oxford.

[18] Saminathan, R. and Kathirvelu, S. 2004. Ethiopian textile industry study report - weaving, Unpublished paper presented at Bahir Dar University Textile \& Garment Symposium.

[19] Sileshi, Z. and Jothi, D. 2004. Ethiopian textile industry study report finishing, Unpublished paper presented at Bahir Dar University Textile \& Garment Symposium. 